\title{
Maltodextrins Based Solid Membranes for the Enantioanalysis of L-Cysteine
}

\author{
Raluca-loana Stefan-van Staden * and Luxolo Holo
}

Laboratory of Electrochemistry and PATLAB Bucharest, National Institute of Research for Electrochemistry and Condensed Matter, 202 Splaiul Independentei Str., 060021, Bucharest, Romania

\begin{abstract}
Three enantioselective membranes based on maltodextrins with different values of dextrose equivalent (DE) were proposed for the enantioanalysis of L-cysteine. The membranes were used for the design of potentiometric sensors. The slopes of the sensors were near-Nernstian (higher than $58.00 \mathrm{mV} /$ decade of concentration) with limits of detection of magnitude order of $10^{-11}$ and $10^{-12} \mathrm{~mol} / \mathrm{L}$. The surfaces of the membranes were stable for more than 6 months of continuous use. They can be renewed by polishing on alumina paper.
\end{abstract}

Keywords: L-cysteine, solid enantioselective membrane, maltodextrin, enantioselective, potentiometric membrane electrode.

\section{INTRODUCTION}

L-Cysteine (L-Cys) is a sulphur-containing amino acid R-SH and one of the twenty basic proteins [1]. It can be used as a prospective radiation protector and cancer indicator [2-5]. The electrochemical study of cysteine has been reported [6-9]. The development of chemically modified amperometric electrodes for detection of cysteine is a growing field [10-16]. Fluorescence was also employed for the assay of cysteine [17].

Chiral recognition is an area of considerable research interest due to its importance in biological, chemical and pharmaceutical sciences [18]. Techniques, which are intensively used for chiral recognition are: chromatography, capillary zone electrophoresis, mass spectrometry and electrochemistry. Utilization of electrochemical techniques will make the enantioanalysis highly reliable [19].

Maltodextrins represents a class of very powerful chiral selectors [20-22]. Variations in DE values result in maltodextrins with varying physico-chemical properties: solubility, hydroscopicity, osmolality and their effectiveness to reduce the freezing point increase with increasing DE, while viscosity, cohesiveness and coarse-crystal prevention increase as DE decreases $[23,24]$. Maltodextrins were used as chiral selectors for enantiomeric separations by capillary zone electrophoresis [21, 22, 25-29], and they were also used for the design of enantioselective, potentiometric membrane electrodes [19, 30-33]. Although, the HPLC

*Address correspondence to this author at the Laboratory of Electrochemistry and PATLAB Bucharest, National Institute of Research for Electrochemistry and Condensed Matter, 202 Splaiul Independentei Str., 060021, Bucharest, Romania; Tel: +40751507779; E-mail: iustinavanstaden@yahoo.com (standard method) method, and fluorescence based method are highly used for biomedical analysis, they cannot always be high reliable especially for urine samples, when the complexity of the sample is very high.

This paper proposed three solid enantioselective membranes used in the design of enantioselective, potentiometric membrane electrodes (EPMEs) for the enantioanalysis of L-cysteine. The membranes were based on maltodextrins with different $D E$.

\section{EXPERIMENTAL}

\subsection{Reagents and Materials}

L- and D-Cysteine were bought from Sigma-Aldrich (St. Louis, MO, USA). Maltodextrins (DE 4.0-7.0, 13.0$17.0,16.5-19.5)$ and graphite powder (1-2 $\mu \mathrm{m}$, synthetic) were bought from Aldrich (Milwaukee, WI, USA).

Deionised water was obtained using a Modulab system (Continental Water Systems, San Antonio, TX, USA). The L- and D-cysteine solutions necessarily in the characterization of the enantioselective, potentiometric membrane electrodes were prepared from standard L- and D-cysteine solutions $\left(10^{-2} \mathrm{~mol} / \mathrm{L}\right)$, respectively, by serial dilutions. All solutions were buffered with phosphate buffer $(\mathrm{pH} 2.40,0.1 \mathrm{~mol} / \mathrm{L})$ from Merck (Darmstadt, Germany) $(1: 1, v / v$, buffer: deionised water).

\subsection{Apparatus}

The potentiometric measurements were done using a system comprising a 663 VA stand (Metrohm, Herisau, Switzerland), a PGSTAT 20 (Eco Chemie, 
Utretch, Netherlands), and a software version 4.9. $\mathrm{Ag} / \mathrm{AgCl}(0.1 \mathrm{~mol} / \mathrm{L} \mathrm{KCl})$ was used as reference electrode in the cell.

\subsection{Solid Membranes and Electrodes Design}

Paraffin oil was added to graphite powder in a ratio of 1:4 (w/w). A solution of maltodextrin (DE 4.0-7.0 (I), 13.0-17.0 (II), or 16.5-19.5 (III); $\left.10^{-3} \mathrm{~mol} / \mathrm{L}\right)$ was added to the paste in a ratio $1: 1(\mu \mathrm{L}: \mathrm{mg})$. The diameter of the active area of the potentiometric, enantioselective membrane electrode was $3 \mathrm{~mm}$. $\mathrm{Ag} / \mathrm{AgCl}$ was used as electric contact. $0.1 \mathrm{~mol} / \mathrm{L} \mathrm{KCl}$ solution was used as internal solution.

\subsection{Recommended Procedures}

Direct potentiometric method was used for all measurements using solution with concentrations between $10^{-10}$ and $10^{-2} \mathrm{~mol} / \mathrm{L}$. The working and reference electrodes were placed in stirred standard solutions. Graphs of $\mathrm{E}(\mathrm{mv})$ versus pL-Cys were plotted and unknown concentrations were determined from the graphs.

\subsubsection{Determination of L-Cysteine in Urine Samples}

Urine samples were collected from different patients

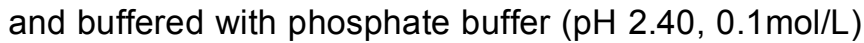
(1:1, v/v, buffer:urine sample). Direct potentiometric method was used to determine L-cysteine in urine samples.

\section{RESULTS AND DISCUSSION}

\subsection{Electrodes Response}

The response characteristics of the electrodes were determined using potentiometric method (Table 1). All calibration equations had correlation coefficients of 0.9999 . The limits of detection are very low - of $10^{-11}$ and $10^{-12} \mathrm{~mol} / \mathrm{L}$ magnitude order. The response of the proposed electrodes was between 58.00 and 60.00
$\mathrm{mV} /$ decade of concentration, very closed with the Nernstian value. The electrodes did not respond for Dcysteine assay; $3-5 \mathrm{mV} /$ decade of concentration was obtained when the three sensors were used.

The proposed electrodes were highly stable and reproducible over 6 months test period (RSD value for the slopes did not exceeded $1 \%$ ). The response time was $20 \mathrm{~s}$ for concentration range $10^{-5}-10^{-3} \mathrm{~mol} / \mathrm{L}$ and $1 \mathrm{~min}$ for concentrations lower than $10^{-5} \mathrm{~mol} / \mathrm{L}$.

\subsection{The Effect of $\mathrm{pH}$ on the Response of the Electrodes}

The influence of $\mathrm{pH}$ on the response of the proposed electrodes was investigated for solutions of $10^{-5} \mathrm{~mol} / \mathrm{L} \mathrm{L}-\mathrm{Cys}$ at different $\mathrm{pH}$ values $(\mathrm{pH} 1-12)$. These solutions were prepared by addition of small volumes of $\mathrm{HCl}$ and/or $\mathrm{NaOH}$ solution $(0.1-1 \mathrm{~mol} / \mathrm{L}$ of each) to a L-Cys solution.

The plots of $E(\mathrm{mV})$ versus $\mathrm{pH}$ (Figure 1) show that the response of the electrodes is not depending on $\mathrm{pH}$, in the following ranges 2.0-5.0, 2.0-7.0, and 2.0-6.0 for the EPMEs based on maltodextrins I, II, and III, respectively.

\subsection{The Selectivity of the Electrodes}

Mixed solution method was used for the study of the selectivity of the proposed electrodes versus D-Cys, polyvinylpyrolidone (PVP), creatine, creatinine, $\mathrm{Na}^{+}, \mathrm{K}^{+}$, and $\mathrm{Ca}^{2+}$. The concentration of the interfering ions and L-Cys were $10^{-4}$ and $10^{-5} \mathrm{~mol} / \mathrm{L}$, respectively. The EPMEs based on maltodextrins were selective over PVP, creatine and creatinine and enantioselective (Table 2). Potentiometic selectivity coefficients were calculated using the equation:

$$
K_{i, j}^{p o t}=\left(10^{\frac{\Delta E}{S}}-1\right) \times \frac{a_{i}}{a_{j}^{z_{i} / z_{j}}}
$$

Table 1: Response Characteristics of Enantioselective, Potentiometric Membrane Electrodes for the Assay of LCysteine

\begin{tabular}{|c|c|c|c|c|}
\hline $\begin{array}{c}\text { EPME based on } \\
\text { maltodextrin }\end{array}$ & $\begin{array}{c}\text { Slope } \\
(\mathbf{m V} / \text { decade of conc.) }\end{array}$ & $\begin{array}{c}\text { Intercept, } \\
\mathrm{E}^{\circ}(\mathbf{m V})\end{array}$ & $\begin{array}{c}\text { Linear } \\
\text { conc. } \\
\text { range (mol/L) }\end{array}$ & $\begin{array}{c}\text { Detection } \\
\text { limit } \\
(\mathbf{m o l} / \mathrm{L})\end{array}$ \\
\hline \hline $\mathrm{I}$ & $58.5 \pm 0.2$ & $587.5 \pm 12.2$ & $10^{-10}-10^{-3}$ & $9.0 \times 10^{-12}$ \\
\hline $\mathrm{II}$ & $59.0 \pm 0.1$ & $659.8 \pm 11.3$ & $10^{-10}-10^{-3}$ & $5.2 \times 10^{-12}$ \\
\hline $\mathrm{III}$ & $59.2 \pm 0.2$ & $600.7 \pm 12.5$ & $10^{-10}-10^{-3}$ & $7.1 \times 10^{-11}$ \\
\hline
\end{tabular}

All measurements were made at $25^{\circ} \mathrm{C}$. All values are averages of ten determinations. 


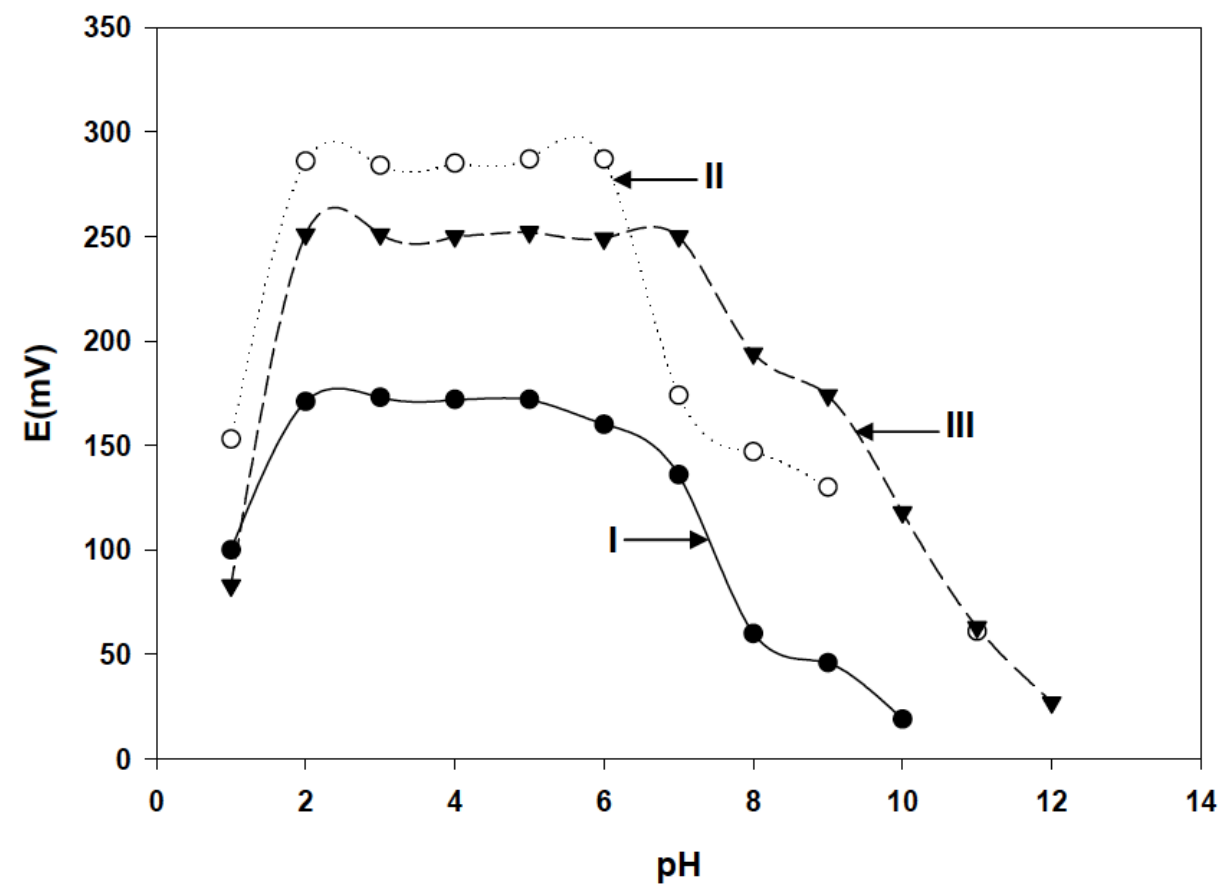

Figure 1: The influence of $\mathrm{pH}$ on the response of the enantioselective, potentiometric membrane electrodes $\left(\mathrm{C}_{\mathrm{L}-\mathrm{Cys}}=10^{-5} \mathrm{~mol} / \mathrm{L}\right)$; I - MD-I, II - MD-III and III - MD-II based EPMEs.

where $\Delta \mathrm{E}$ is the difference between the potential recorded for mixed solution $\left(E_{i, j}\right)$ and for the solution that contains only the main ion $\left(E_{i}\right), \Delta E=E_{i, j}-E_{1}$ (all recorded in $\mathrm{mV}$ ); $S$ is the slope of the electrode deducted from the equation of calibration ( $\mathrm{mV} /$ decade of concentration); $a_{i}$ is the activity of the main ion, $\mathrm{i}, a_{j}$ is the activity of interfering species, $j ; z_{i}$ is the charge of the main ion, $i, z_{j}$ is the charge of interfering species, $j$.

Inorganic ions such as $\mathrm{Na}^{+}, \mathrm{K}^{+}$, and $\mathrm{Ca}^{2+}$ did not interfere with the analysis of L-Cys, because the potentiometric selectivity coefficients calculated were less than $10^{-4}$.

\subsection{Analytical Applications}

Recovery tests were performed first for the assay of $\mathrm{L}$-cys in the presence of $\mathrm{D}$-cys; different ratios between
L- and D-Cys concentrations were used. The results obtained (Table 3) demonstrated that D-Cys did not interfere in the assay of L-Cys.

L-cysteine was reliable determined in urine samples; results are shown in Table 4.

The average recovery of L-cysteine in urine samples was higher that $99 \%$ from the amount of $L$ cysteine determined using a standard method - HPLC [34]. These values were taken as reference for the validation of the proposed method.

\section{CONCLUSION}

Maltodextrins were excellent chiral selectors for the design of enantioselective membranes. The construction of the membranes was simple, fast, and

Table 2: Potentiometric, Selectivity Coefficients of the Electrodes Used for the Enantioanalysis of L-Cysteine

\begin{tabular}{|c|c|c|c|}
\hline \multirow{2}{*}{$\begin{array}{c}\text { Interfering species } \\
(J)\end{array}$} & \multicolumn{3}{|c|}{$K_{i, j}^{\text {pot }}$} \\
\cline { 2 - 4 } & MD-I & MPME based on \\
\cline { 2 - 4 } & $6.0 \times 10^{-3}$ & $8.1 \times 10^{-4}$ & $4.0 \times 10^{-4}$ \\
\hline \hline D-Cys & $3.2 \times 10^{-3}$ & $3.2 \times 10^{-3}$ & $8.1 \times 10^{-4}$ \\
\hline PVP & $4.0 \times 10^{-4}$ & $3.3 \times 10^{-3}$ & $4.0 \times 10^{-4}$ \\
\hline Creatine & $<<1.0 \times 10^{-4}$ & $4.0 \times 10^{-4}$ & $8.1 \times 10^{-4}$ \\
\hline Creatinine & & & \\
\hline
\end{tabular}

All measurements were made at $25^{\circ} \mathrm{C}$. All values are averages of ten determinations. 
Table 3: Determination of L-Cysteine in the Presence of D-Cysteine

\begin{tabular}{|c|c|c|c|}
\hline \multirow{2}{*}{\begin{tabular}{c}
\multirow{2}{*}{$\begin{array}{c}\text { L:D } \\
\text { mol/mol }\end{array}$} \\
\cline { 2 - 4 }
\end{tabular}} & \multicolumn{3}{|c|}{ L-cys, Recovery, \% } \\
\cline { 2 - 4 } & I & EPME based on MD & II \\
\hline \hline $2: 1$ & $99.63 \pm 0.01$ & $99.72 \pm 0.02$ & $99.98 \pm 0.02$ \\
\hline $1: 1$ & $99.95 \pm 0.02$ & $99.99 \pm 0.01$ & $99.60 \pm 0.02$ \\
\hline $1: 2$ & $99.81 \pm 0.02$ & $100.00 \pm 0.01$ & $99.24 \pm 0.01$ \\
\hline $1: 4$ & $99.90 \pm 0.01$ & $99.97 \pm 0.02$ & $100.00 \pm 0.01$ \\
\hline $1: 9$ & $99.54 \pm 0.02$ & $99.99 \pm 0.01$ & $99.99 \pm 0.02$ \\
\hline
\end{tabular}

All measurements were made at $25^{\circ} \mathrm{C}$. All values are averages of ten determinations.

Table 4: Determination of L-Cysteine in Urine Samples

\begin{tabular}{|c|c|c|c|c|}
\hline \multirow{2}{*}{ Urine sample } & \multicolumn{4}{|c|}{ L-cys, Recovery } \\
\cline { 2 - 5 } & \multicolumn{2}{|c|}{ EPME based on MD, \% from the amount determined using HPLC } & \multicolumn{2}{c|}{$\begin{array}{c}\text { HPLC [34], } \\
\text { mol/L }\end{array}$} \\
\cline { 2 - 5 } & I & III & $99.99 \pm 0.25$ & $2.3 \times 10^{-6}$ \\
\hline \hline 1 & $99.42 \pm 0.20$ & $99.80 \pm 0.15$ & $99.59 \pm 0.20$ & $2.7 \times 10^{-7}$ \\
\hline 2 & $99.50 \pm 0.15$ & $99.58 \pm 0.18$ & $99.49 \pm 0.10$ & $3.2 \times 10^{-7}$ \\
\hline 3 & $99.09 \pm 0.20$ & $99.86 \pm 0.21$ & $99.99 \pm 0.21$ & $4.3 \times 10^{-7}$ \\
\hline 4 & $100.01 \pm 0.21$ & $100.00 \pm 0.20$ & $99.57 \pm 0.21$ & $4.0 \times 10^{-7}$ \\
\hline 5 & $99.87 \pm 0.10$ & $99.85 \pm 0.12$ & $99.19 \pm 0.18$ & $3.9 \times 10^{-7}$ \\
\hline 6 & $99.39 \pm 0.15$ & $99.66 \pm 0.20$ & & \\
\hline
\end{tabular}

All measurements were made at $25^{\circ} \mathrm{C}$. All values are averages of ten determinations.

reproducible. The electrodes' selectivity and enantioselectivity made them suitable for enantioanalysis of L-Cysteine in urine samples. The best maltodextrin based electrode for the enantioanalysis of L-cysteine proved to be the one based on maltodextrin III because it exhibited the best selectivity and enantioselectivity as well as the highest slope. Accordingly, this electrode is the electrode of choice for the enantioanalysis of L-cysteine.

\section{ACKNOWLEDGEMENTS}

The authors are grateful to the PNII Program Capacity, 2012-2014, Contract nr. 3ERC-like/2012 for financial support.

\section{REFERENCES}

[1] Voet D, Voet JG, Biochemistry, $2^{\text {nd }}$ ed., New York: Wiley 1995, p. 1263.

[2] Kulys J, Drungiliene A, Chemically modified electrodes for the determination of sulphydryl compounds. Anal. Chim. Acta 1991; 243: 287-92. http://dx.doi.org/10.1016/S0003-2670(00)82572-6

[3] Townshend A Ed., Encyclopedia of Analytical Science, Vol. 3, London: Academic Press 1995, p. 1735.
[4] Filanovsky B, Electrochemical response of new carbon electrodes bulk modified with cobalt phthalocyanine to some thiols in the presence of heptane or human urine. Anal Chim Acta 1999; 394: 91-100.

http://dx.doi.org/10.1016/S0003-2670(99)00035-5

[5] Nagasawa HT, Elberling JA, Roberts JC, Beta-substituted cysteines as sequestering agents for ethanol-derived acetaldehyde in vivo. J Med Chem 1987; 30: 1373-8. http://dx.doi.org/10.1021/im00391a018

[6] Persson B, A Chemically modified graphite electrode for electrocatalytic oxidation of reduced nicotinamide adenine dinucleotide based on a phenothiazine derivative, 3- $\beta$ naphthoyl-toulidine blue. J Electroanal Chem 1990; 287: 6180.

http://dx.doi.org/10.1016/0022-0728(90)87160-L

[7] Ke B. The polarographic behaviour of $\alpha$-lipoic acid. Biochem Biophys Acta 1957; 25: 650-1.

http://dx.doi.org/10.1016/0006-3002(57)90544-9

[8] Zagal JH, Metallophthalocyanines as catalyst in electrochemical reactions. Coord Chem Rev 1992; 119: 89136. http://dx.doi.org/10.1016/0010-8545(92)80031-L

[9] Arrigan DWM, Bihan LL. A study of L-cysteine adsorption on gold via electrochemical desorption and copper (II) ion complexation. Analyst 1999; 124: 1645-9. http://dx.doi.org/10.1039/a905370k

[10] Chen SM. Electrocatalytic reaction, catalytic autoxidation, and supported catalytic autoxidation of sulfur oxoanions by FeTSPP and Mn(4-TMPyP). J Electroanal Chem 1996; 407: 123-30.

http://dx.doi.org/10.1016/0022-0728(95)04464-7 
[11] Zagal JH, Aguirre MJ, Parodi CG, Sturm J, Electrocatalytic activity of vitamin $B_{12}$ adsorbed on graphite electrode for the oxidation of cysteine and glutathione and the reduction of cysteine. J Electroanal Chem 1994; 374: 215-22.

http://dx.doi.org/10.1016/0022-0728(94)03365-X

[12] Sugawara K, Hoshi S, Akatsuka K, Shimazu K, Electrochemical behaviour of cysteine at a Nafion ${ }^{\circledR} \mid \operatorname{cobalt}(\mathrm{II})$ modified electrode. J Electroanal Chem 1996; 414: 253-6.

[13] Sugarawa K, Tanaka S, Taga M. Voltametric behaviour of cysteine by a carbon-paste electrode containing cobalt(II) cyclohexylbutyrate. Bioelectrochem Bioenerg 1991; 26: 46974.

\section{http://dx.doi.org/10.1016/0302-4598(91)85008-P}

[14] Halbert MK, Baldwin RP. Electrocatalytic and analytical response of cobalt phthalocyanine containing carbon paste electrodes toward sulfhydryl compounds. Anal Chem 1985; 57: 591-5.

http://dx.doi.org/10.1021/ac00280a007

[15] Mafatle TJ, Nyokong T. Electrocatalytic oxidation of cysteine by molybdenum (V) phthalocyanine complexes. J Electroanal Chem 1996; 408: 213-8.

http://dx.doi.org/10.1016/0022-0728(95)04519-8

[16] Pang DW, Wang ZL, Electrocatalysis of metalloporphyrins: Part 13. Electrocatalysis of several water-soluble porphyrins for the oxidation of some small molecules. J Electroanal Chem 1993; 358: 235-46.

http://dx.doi.org/10.1016/0022-0728(93)80441-J

[17] Huang S, Xiao Q, Li R, Guan HL, Liu J, Liu XR, He ZK, Liu Y, A simple and sensitive method for I-cysteine detection based on the fluorescence intensity increment of quantum dots. Anal Chim Acta 2009; 645: 73-8.

http://dx.doi.org/10.1016/j.aca.2009.04.034

[18] Aboul-Enein HY, Wainer IW. The Impact of Stereochemistry on Drug Development and Use, New York: Wiley 1997.

[19] Stefan RI, van Staden JF, Aboul-Enein HY, Electrochemical Sensors in Bioanalysis, New York: Marcel Dekker 2001.

[20] Soini M, Stefansson M, Riekkola ML, Novotny NV. Maltooligosaccharides as chiral selectors for the separation of pharmaceuticals by capillary electrophoresis. Anal Chem 1994; 66: 3477-84. http://dx.doi.org/10.1021/ac00092a028

[21] Huslt $A D$, Verbeke $N$, Separation of the enantiomers of coumarinic anticoagulant drugs by capillary electrophoresis using maltodextrins as chiral modifiers. Chirality 1994; 6: 225-9.

[22] Huslt $A D$, Verbeke $N$. Chiral analysis of basic drugs by oligosaccharide mediated capillary electrophoresis. J Chromatogr A 1996; 735: 283-93.

http://dx.doi.org/10.1016/0021-9673(95)01356-3
[23] Altshul AM, Low caloric foods-a scientific status summary by the Institute of Food Technologies expert panel of food safety and nutrition. Food Technol 1989; 43: 113-20.

[24] Chronakis IS, On the molecular characteristics, compositional properties and and structural-functional mechanism of the maltodextrins: a review, Crit Rev Food Sci. 1998; 38: 599-637.

http://dx.doi.org/10.1080/10408699891274327

[25] Huslt AD, Verbeke N. Chiral separation by capillary electrophoresis with oligosaccharides. J Chromatogr 1992; 608: 275-87.

http://dx.doi.org/10.1016/0021-9673(92)87134-T

[26] Huslt AD, Verbeke N. Quantitation in chiral capillary electrophoresis; theoretical and practical consideration. Electrophoresis 1994; 15: 854-63. http://dx.doi.org/10.1002/elps.11501501121

[27] Huslt AD, Verbeke N, Carbohydrates as chiral selectors for capillary electrophoresis. Enantiomer 1997; 2: 69-79.

[28] Watanabe T, Takahasi K, Horiuchi M, Kato K, Nakazawa H, Sugimoto $\mathrm{T}$, Kanazawa $\mathrm{H}$, Chiral separation and quantitation of pentazocine enantiomers by Capillary zone electrophoresis using maltodextrins. J Pharm Biomed Analysis 1999; 21: 75-81. http://dx.doi.org/10.1016/S0731-7085(99)00114-4

[29] Quang C, Khaledi MG. Direct separation of enantiomers of beta-blockers by cyclodextrin-mediated capillary zone electrophoresis. J High Resolut Chromatogr 1994; 17: 60912.

http://dx.doi.org/10.1002/jhrc.1240170810

[30] Ozoemena KI, Stefan RI, van Staden JF, Aboul-Enein HY, Utilization of maltodextrin based enantioselective, potentiometric membrane electrodes for the enantioselective assay of S-perindopril. Talanta 2004; 62: 681-5.

http://dx.doi.org/10.1016/j.talanta.2003.08.035

[31] Nejem RM, Stefan RI, van Staden JF, Aboul-Enein HY, Enantioanalysis of L-hydroxyglutaric acid in urine samples using enantioselective, potentiometric membrane electrodes based on maltodextrins. Talanta 2005 65: 437-0.

http://dx.doi.org/10.1016/j.talanta.2004.06.040

[32] Stefan RI, Nejem RM, Enantioanalysis of glyceric acid in urine samples using enantioselective, potentiometric membrane electrodes based on maltodextrins. Sens Actuators B 2005 106: 736-0. http://dx.doi.org/10.1016/j.snb.2004.09.031

[33] Stefan-van Staden RI, Bokretsion RG, van Staden JF, AboulEnein HY, Enantioanalysis of butaclamol using enantioselective, potentiometric electrodes. Anal Lett 2009 42: 1111-8. http://dx.doi.org/10.1080/00032710902890462

[34] Wootton IDP. Micro-analysis in Medical Biochemistry (4th Edition), London: J.A. Chuchill Ltd. 1964. 